\title{
Using Nutrient Uptake Patterns to Develop Efficient Nitrogen Management Strategies for Vegetables
}

Charles A. Sanchez ${ }^{1}$ and Thomas A. D oerge ${ }^{2}$

Summary. N itrogen (N) in a soil that is not immediately taken up by a crop is subject to leaching, denitrification and other mechanisms of loss. N itrogen uptake studies identify the total amount of $\mathbf{N}$ accumulated by the crop and the period of peak demand. This information can be used to devise management strategies aimed at supplying $\mathbf{N}$ preceding anticipated uptake. Split sidedress application, fertigation, and use of controlled release fertilizers (CRN ) are all viable options for $\mathbf{N}$ management, depending on the crop production scenario and available infrastructure. Soil and plant tissue testing can be useful feedback tools for adjusting $\mathbf{N}$ applications for soil contributions of $\mathbf{N}$ and unexpected $\mathbf{N}$ losses. E fficient irrigation is of paramount importance in achieving efficient $\mathbf{N}$ fertilization regardless of management practice.

$\mathrm{N}$

itrogen is the fertilizer element required in the greatest quantities by most crops. The $\mathrm{N}$ available to crops might include symbiotically fixed $\mathrm{N}$, residual soil organic and inorganic $\mathrm{N}$, and soil applied organic and inorganic N . O nly leguminous vegetable crops, such as peas (Pisum sativum L.) and beans (Phaseolus vulgaris $\mathrm{L}$.) , may derive a significant portion of their $\mathrm{N}$ requirement by symbiotic $\mathrm{N}$ fixation. While some soils have sizeable organic fractions where soil $\mathrm{N}$ mineralization can contribute significantly to a crops $\mathrm{N}$ requirement, only vegetable crops produced on organic soils (H istosols) derive most or all of their $\mathrm{N}$ through soil $\mathrm{N}$ mineralization. Although some organically grown vegetables rely almost exclusively on $\mathrm{N}$ mineralized from soil applied organic $\mathrm{N}$ sources, most of the $\mathrm{N}$ requirement of commercial vegetables is met by the addition of synthetic fertilizers. I deally, $\mathrm{N}$ from all sources should become available to a crop at a rate about equal to its $\mathrm{N}$ uptake requirement. The availability of $\mathrm{N}$ in amounts exceeding the immediate requirements of the crop will remain unused in the soil. This nitrogen is subject to leaching, denitrification and other mechanisms of loss. Therefore, $\mathrm{N}$ fertilization practices and other management decisions that influence $\mathrm{N}$ availability should take into consideration crop $\mathrm{N}$ demand and uptake patterns.

\footnotetext{
The cost of publishing this paper was defrayed in part by the payment of page charges. U nder postal regulations, this paper therefore must be hereby marked advertisement solely to indicate this fact.

1Yuma Agricultural Research Center, The U niversity of Arizona, 6425 West 8th Street, Yuma, AZ 85364

2Pioneer H i-Bred, 7100 N W 62nd Avenue, Johnston, IA 50131.
} 
Fig. 1. Seasonal nitrogen (N) accumulation by broccoli fit to nitrogen accumulation $(\mathrm{NA})=(\mathrm{a} /(1+$ $\exp (b-c t))$ ), where $t$ is time in days and $a, b$, and $c$ are constants (A) and daily $\mathbf{N}$ flux, which is given by taking the first derivative of the above equation with respect to time (t) to become dN A/dt $=a c(\exp (b$ - ct) $) /(1+\exp (b-$ (t) ${ }^{2}$ ) (B). Figures generated from unpublished data of C.A. Sanchez, which were obtained from field experiment with furrow irrigated broccoli; 1 kg $\cdot$ ha $^{-1}$ $=0.89 \mathrm{lb} / \mathrm{acre}$.

Fig. 2. Nitrogen (N) accumulation of lettuce by days after planting (A) and effective degree days (EDD) (B). $\mathbf{1} /$ EDD $=1 / D D+\alpha /$ $S R$, where $D D$ is degree day accumulation, SR is daily solar radiation, and $\alpha$ is a constant obtained by model fit but for this preliminary evaluation we used $\alpha=0.5$ after $\mathbf{W}$ urr et al., (1988). Figures derived from unpublished data of C.A. Sanchez, which were obtained from field experiments with furrow irrigated lettuce; 1 $\mathrm{kg} \cdot \mathrm{ha}^{-1}=0.89 \mathrm{lb} /$ acre.
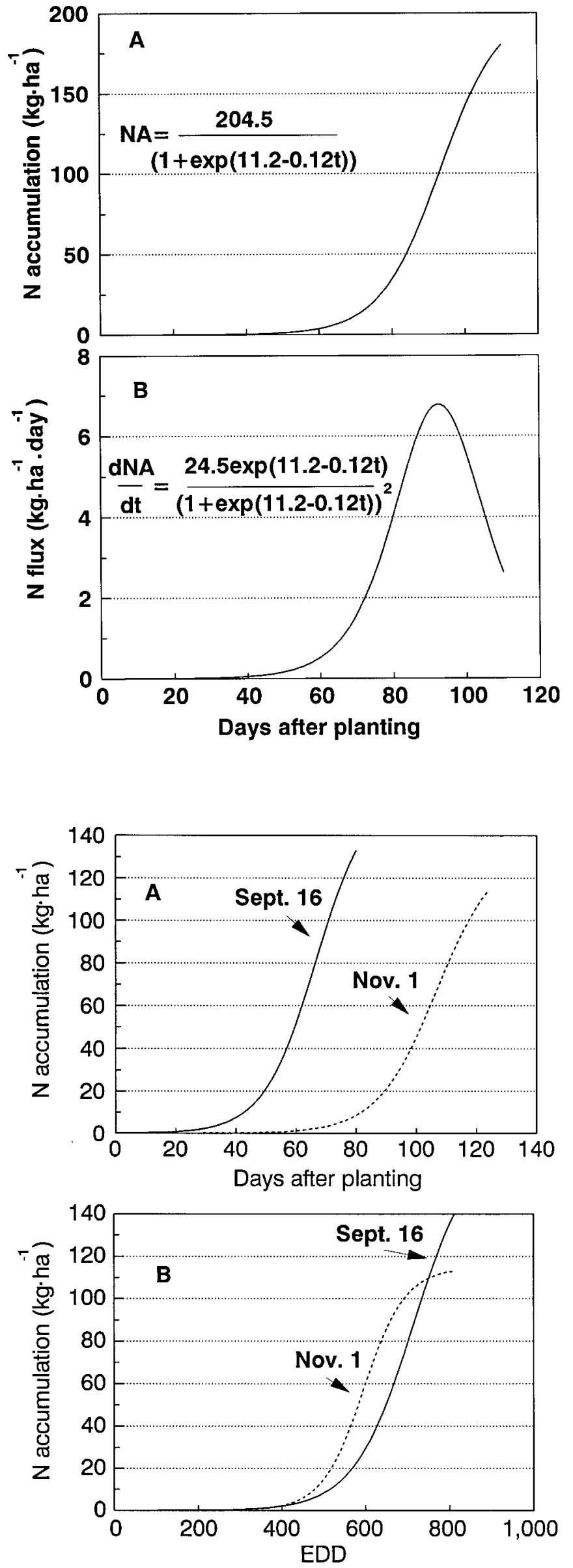

\section{Nitrogen accumulation and flux}

Experiments that generate $\mathrm{N}$ uptake data are useful for determining the total $\mathrm{N}$ contained in the crop biomass and identifying periods of peak demand. $\mathrm{N}$ itrogen uptake is often approximated by measuring total $\mathrm{N}$ accumulation in aboveground whole plants at selected intervals during the growing season. $\mathrm{N}$ itrogen flux density is uptake per unit time and is determined by taking the first derivative of a fitted $\mathrm{N}$ accumulation function. Thereare several possible mathematical functionsthat can beused to approximate $\mathrm{N}$ accumulation patterns.

$\mathrm{N}$ itrogen accumulation and flux for furrow irrigated broccoli (Brassica ol eracea L. I talica G roup) in A rizonaare shown in Fig. 1. Daily uptake of $\mathrm{N}$ by broccoli is very slow for the first $40 \mathrm{~d}$ after planting, but increases to $\approx 7 \mathrm{~kg} \cdot \mathrm{ha}^{-1}(6.3$ $\mathrm{lb} / \mathrm{acre}$ ) by $90 \mathrm{~d}$. Because this crop is harvested prior to completing its reproductive growth stages, $\mathrm{N}$ uptake remainsrelatively high until harvest. These data for broccoli are generally similar to that for other cool season leafy vegetables (D oerge et al., 1991) and show that $\geq 80 \%$ to $90 \%$ of the $\mathrm{N}$ is taken up during the last half of the growing period.

In the aforementioned examples, $\mathrm{N}$ uptake and flux were expressed using days after planting (DAP) astheexpression of time. H owever, the use of D AP may be less useful in areas where crops are planted over a range of air and soil temperatures. U nder these conditions, timein D AP isnot a reliable predictor of growth stage and the use of heat unitsor some sort of solar-thermal unit may be more useful. $\mathrm{H}$ eat units are likely to be better suited for most warm season vegetables (Arnold, 1974; Katz, 1952). H owever, for cool season crops such as lettuce (Lactuca sativa L.), where response to temperature is heavily influenced by response to light, a combined heat-solar model is likely required (M adariaga and Knott, 1951; Sanchez et al., 1986). O ne approach used with successistheeffectivedegreeday (EDD) concept, which includes summations of temperature and solar radiation (Wurr et al., 1988). The N uptake patterns for furrow irrigated lettuce planted at two different dates in southwestern A rizona are shown in Fig. 2. N ote that while $\mathrm{N}$ uptake patternswere offset substantially during the cooler season when plotted 
Fig. 3. Nitrogen (N) accumulation by lettuce as influenced by $\mathbf{N}$ fertilization rate. Figure generated with unpublished data of C.A. Sanchez, which were obtained from field experiments evaluating $\mathbf{N}$ rate and $\mathbf{N}$ source for furrow irrigated desert lettuce The $N$ rates were split into three equal applica tions; 1 kg.ha-1 = $0.89 \mathrm{lb} / \mathrm{acre}$

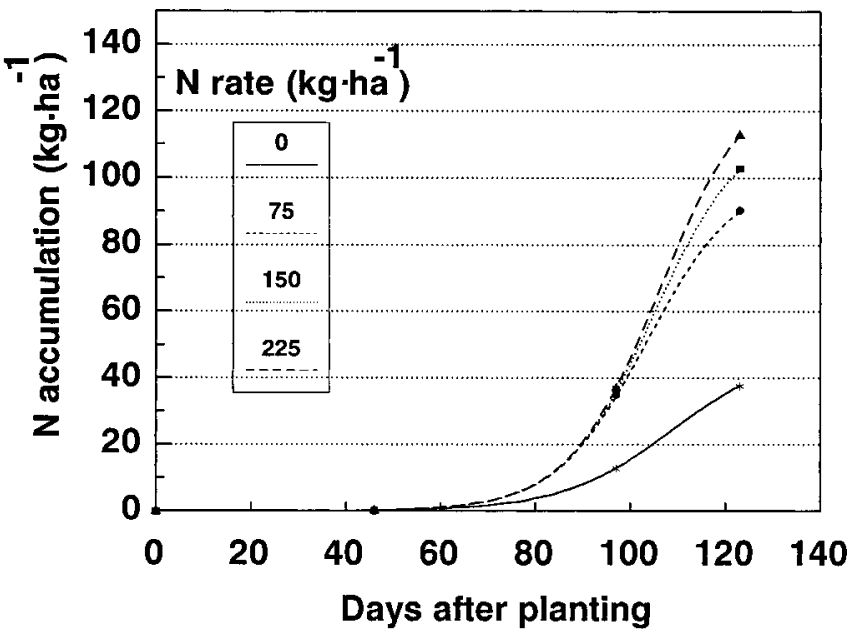

by $D A P$, they were more similar when plotted using the EDD units. We wish to stress that this is only a preliminary evaluation and we are currently conducting research aimed at identifying the most useful approach for predicting

\section{Single N Application}

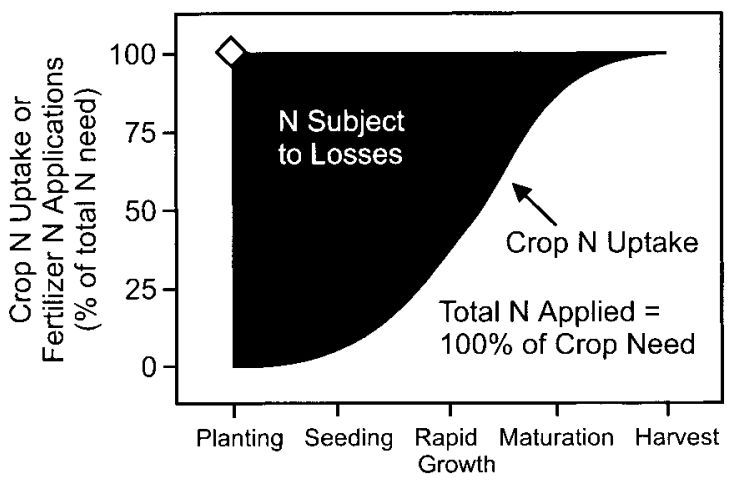

Crop Growing Season

\section{Split N Applications}

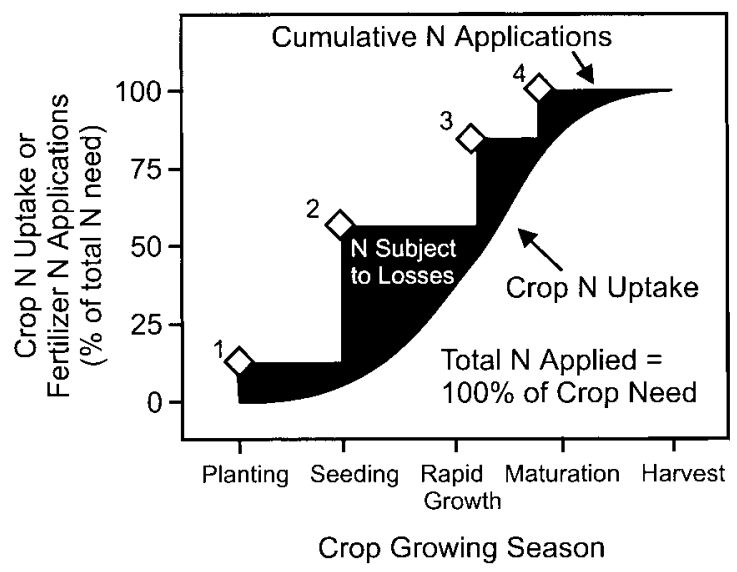

Fig. 4. Potential nitrogen (N) losses under a single preplant $\mathbf{N}$ application (A) or incremental split $\mathrm{N}$ application (B). Adapted from Doerge et al. (1991). growth stage and maturity. N evertheless, these data show that weather based summation models will likely provide the more reliable approach for predicting $\mathrm{N}$ uptake patterns. Finally, data for determining $N$ uptake patterns should be collected under conditionswhereN isnotlimiting marketable yield. The data in Fig. 3 werecollected from an $\mathrm{N}$ rate study with furrow irrigated lettuce in Arizona. $\mathrm{N}$ itrogen accumulation by lettuce was low through 60
DAP for all $N$ rates but between 60 DAP and 120 DAP uptake patterns varied by $\mathrm{N}$ rate and final $\mathrm{N}$ accumulation depended on $\mathrm{N}$ rate.

\section{Nitrogen application, timing, and availability}

The application of $\mathrm{N}$ should be timed to coincide with the characteris-

Fig. 5. R esponse of cool season vegetable crops to $\mathrm{N}$ management: (A) lettuce on silty clay with $\mathrm{N}$ at $200 \mathrm{~kg}^{\cdot \mathrm{ha}^{-1}}$, (B) broccoli on sandy loam with $\mathbf{N}$ at 300 $\mathrm{kg}^{-h^{-1}}(\mathrm{C})$ lettuce on loamy sand with $\mathrm{N}$ at $300 \mathrm{~kg}^{-\mathrm{ha}^{-1}}$ (D) cauliflower on loamy sand where $\mathbf{N}$ for PP and SD were applied at $320 \mathrm{~kg}^{-h a^{-1}}$ and $\mathrm{N}$ with controlled release N (CRN) products were applied at $270 \mathrm{~kg}^{-h^{-1}}$. Controls did not receive $\mathbf{N}$ fertilizer except a small amount applied with preplant phosphorus over the entire experiment area. PP indicated preplant application of soluble $\mathbf{N}$ fertilizer and SD indicates split sidedress application of soluble $\mathrm{N}$ fertilizer. C RN 90 and C R N 120 are controlled release $\mathrm{N}$ fertilizers with designations of rate of $\mathbf{N}$ release of 90 and $120 \mathrm{~d}$ based on designated heat unit accumulation. Bars (I) show LSD values for treatment comparisons (C. A.

Sanchez, unpublished data); $1 \mathrm{Mg}^{\cdot h^{-1}}{ }^{-1}=$ $892 \mathrm{lb} /$ acre and $1 \mathrm{~kg}^{\circ} \cdot \mathrm{ha}^{-1}=0.89 \mathrm{lb} / \mathrm{acre}$.

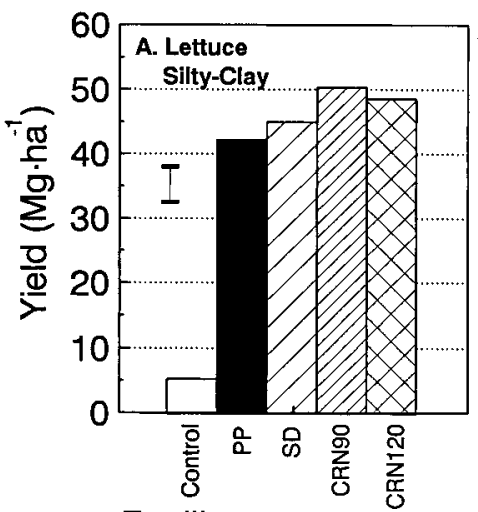

Fertilizer management

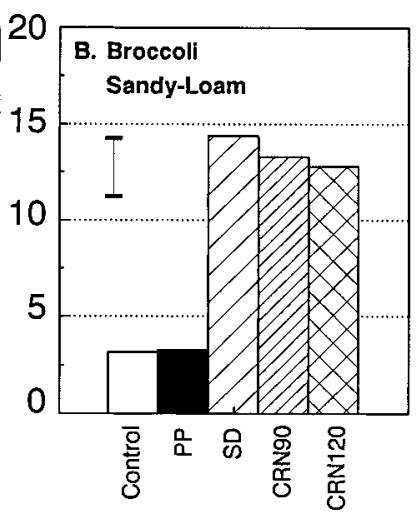

Fertilizer management

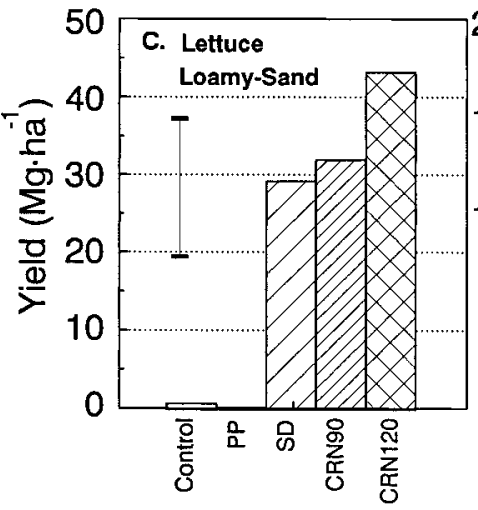

Fertilizer management

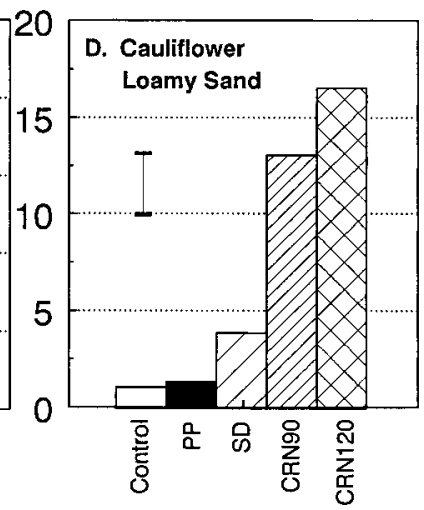

Fertilizer management 
Table 1. The minimum number of $\mathbf{N}$ applications recommended for varying soil types. ${ }^{z}$

Soil

texture

Clay, sandy clay, silty clay

Clay loam, silty clay loam, silt, silt loam, sandy clay loam

Sandy loam and loam

Sand
Recommended $\mathrm{N}$ applications per crop (no.)

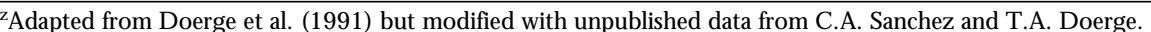

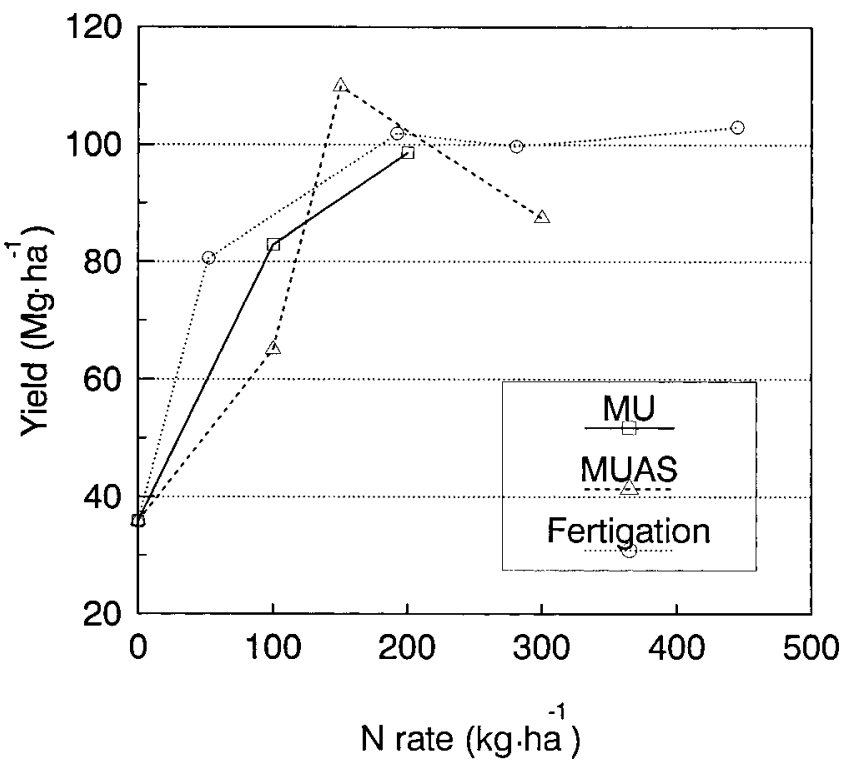

ticipated $\mathrm{N}$ uptake. The release patterns for CRN products are typically defined by the number of daysrequired for releasing $80 \%$ of the $\mathrm{N}$ at some base temperature (often 20 $\left.{ }^{\circ} \mathrm{C}, 68^{\circ} \mathrm{F}\right)$. H owever, experimental verification of field performance for individual crops during specific seasons is usually required. Similarly, field evaluation of organic fertilizers is usually required to insure mineraliza-

Fig. 6. M arketable yield of watermelons to fertigation and two controlled release nitrogen ( $C R N$ ) sources. MU is methylene urea and MUAS is a blend of methylene urea and ammonium sulfate (adapted from Doerge

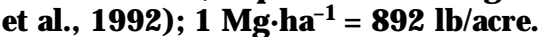

tic $\mathrm{N}$ uptake pattern of the crop. We illustrate this point in Fig. 4 where the potential for $\mathrm{N}$ loss from the soil is much higher if all required $\mathrm{N}$ is made available early during the growing season, compared to becoming incrementally available during the growing season. $\mathrm{N}$ itrogen management must also consider the lag time between application of fertilizer and $\mathrm{N}$ availability. At low soil temperatures where urea hydrolysis and nitrification reaction rates slow considerably, plant growth and $\mathrm{N}$ uptake rates are also reduced. H ence, there is rarely a difference in $\mathrm{N}$ availability and crop responseamong soluble N sources (Gardner and Pew, 1979; Walworth et al., 1992). H owever, for controlled release $\mathrm{N}$ fertilizers ( $\mathrm{CRN}$ ) and most organic fertilizers, the time of fertilizer release and/ or mineralization, respectively, should precede an- tion rates correspond closely to crop demand.

From 1991 to 1998, we conducted several experiments aimed at evaluating $\mathrm{N}$ management strategies for furrow irrigated cool season vegetables. $\mathrm{N}$ itrogen management treatments evaluated included the preplant application of conventional soluble $\mathrm{N}$ fertilizers (PP), the split sidedress application of soluble $\mathrm{N}$ fertilizers (SD), and the preplant application of CRN .

The experiments included lettuce, broccoli, and cauliflower (Brassica oleracea L. Botrytis Group) and were randomized complete block designs with at least four replications. On fine to medium textured soils, both SD and CRN were often superior to PP (Fig. 5a and b), but differencesbetween SD and CRN were minimal. H owever, on coarse textured soils
CRN frequently outperformed SD (Fig. 5c and d). These observationsare generally consistent with other data that we (Sanchez, unpublished) and others (Wiedenfield, 1986; Cook and Sanders, 1991 ) have collected and show the benefit of controlled release fertilizers when conditions for $\mathrm{N}$ losses are high. The consistent superior performance of CRN compared to SD on sandy soilsislikely a logistical limitation of field sidedress $\mathrm{N}$ applications rather than an actual failure in the efficacy of split N application. Sidedress N applications are made prior to irrigation and rarely, are more than four or five irrigations needed for furrow irrigated cool season vegetables. Additionally, rows have to be spiked and cultivated before each sidedress application and furrows and bedsare reshaped after each sidedress application. H ence, it is rare to make more than three sidedress $\mathrm{N}$ applications. Sidedress application on sandy soils often fails to supply $\mathrm{N}$ as frequently as needed for optimal $\mathrm{N}$ use efficiency. The minimum number of nitrogen applications per crop cycle recommended by the $U$ niversity of A rizona for varying soil types is shown in Table 1.

When irrigation infrastructure permits, fertigation is often an effective means of achieving frequent split applications. The data in Fig. 6 show that watermelons (C itrullus lanatus Thunb.) produced on a sandy loam in

Fig. 7. M arketable yield response of lettuce by nitrogen $(\mathrm{N})$ rate to sprinkler applied $\mathbf{N}$ where yield $(\mathbf{Y})=$ $-26.8+0.388 N-0.0006 N^{2} ; R^{2}=$ 0.64 and controlled release nitrogen (CRN) where $Y=10.3-0.070 \mathrm{~N}+$ $0.0020 ; R^{2}=0.70$. D ata generated from unpublished data of Sanchez; 1

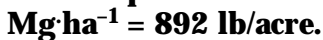

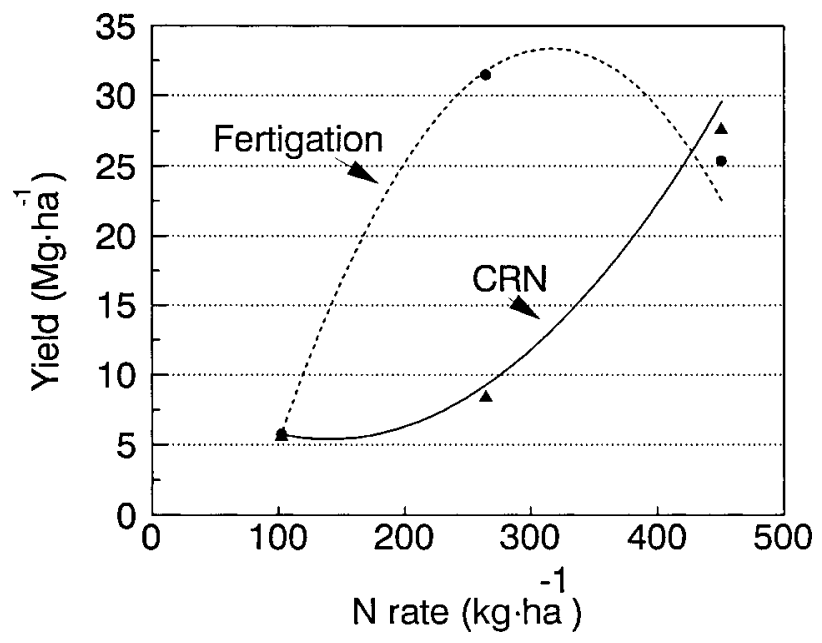




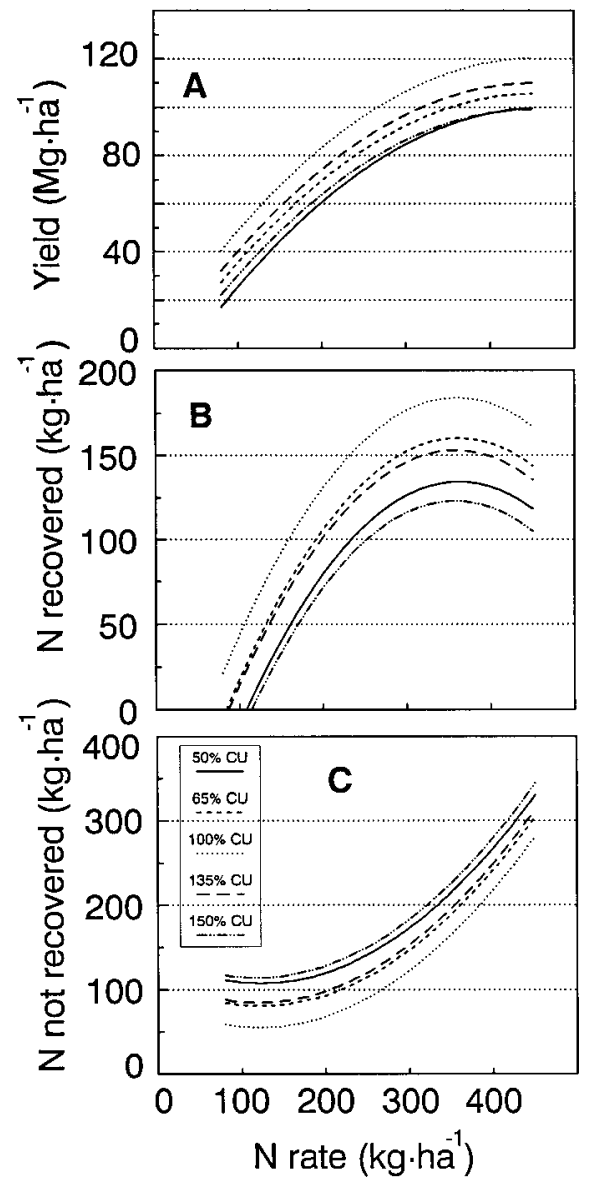

Fig. 8. Predicted marketable yield of cabbage (A) nitrogen (N) accumulation in the marketable harvest (B), and $\mathbf{N}$ that was applied but not recovered in the marketable harvest (C), during an irrigation and $\mathrm{N}$ fertilization experiment conducted on a sandy soil. Adapted from Sanchez et al. (1994). C U is consumptive use or estimated evapo-

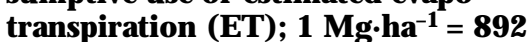
$\mathrm{lb} /$ acre and $1 \mathrm{~kg} \cdot \mathrm{ha}^{-1}=0.89 \mathrm{lb} / \mathrm{acre}$. central Arizona showed a similar response to CRN and fertigation. The data for lettuce shown in Fig. 7 is from a study conducted on a Superstition sand in southwest Arizona. In this experiment, fertigation through the sprinkler system outperformed preplant application CRN . The midrib nitrate$\mathrm{N}$ data suggest that release of $\mathrm{N}$ from the CRN product used did not precede or parallel the crop $\mathrm{N}$ demand (datanot shown). Thereisno question that we might have obtained more comparable results between the two methods of $\mathrm{N}$ fertilization had we successfully selected a $C R N$ product with a release rate more closely matching $\mathrm{N}$ uptake during this particular growing season. N evertheless, these data bring to light the risks of committing to a strategy early compared to making adjustments throughout the growing season. I t is the opinion of the authors, that in thewestern $U$ nited States, where virtually the entire water requirement of the crop is applied by irrigation, the best CRN product can only perform as well as properly managed fertigation. $\mathrm{H}$ owever, in the humid regions where the need to irrigate is problematic the use of CRN may be more effective even where infrastructure for fertigation is available.

\section{Soil and plant monitoring}

The actual rate of fertilizer $\mathrm{N}$ applied should be adjusted based on the

Fig. 9. Seasonal midrib nitrate-N concentrations of cabbage at three irrigation regimes compared to critical concentration; $\mathbf{1} \mathbf{~ g} \cdot \mathbf{k g}^{-1}=$ 1000 ppm. Adapted from Sanchez et al. (1994).

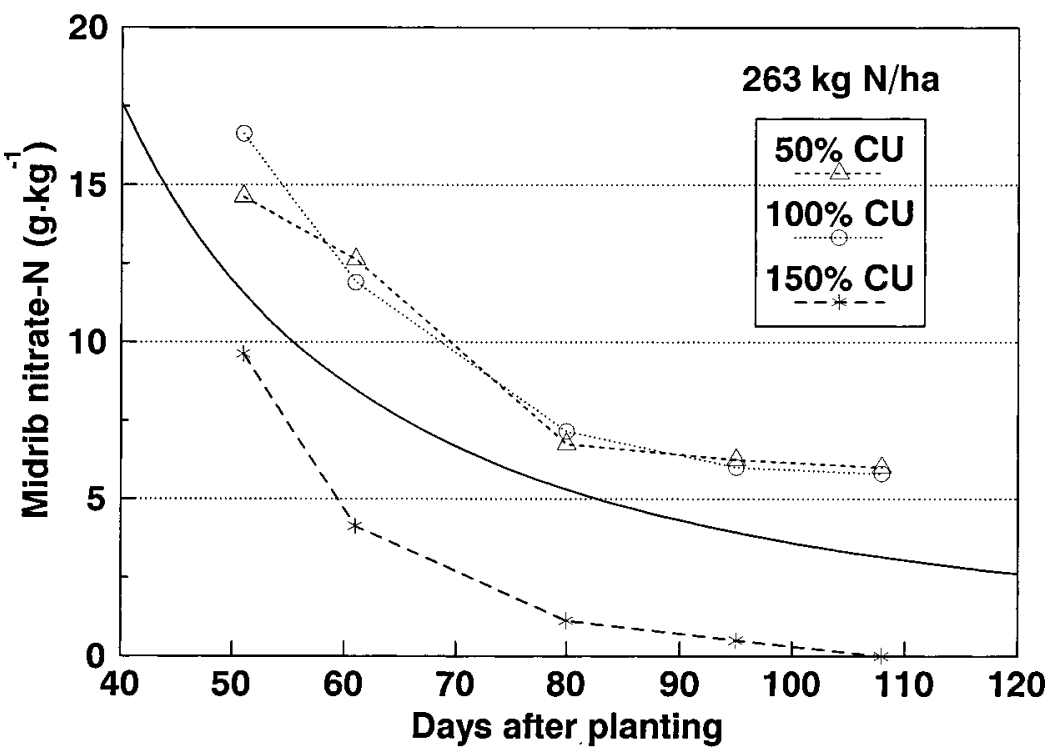

contributions of soil $\mathrm{N}$ (primarilymineralization) and unexpected $\mathrm{N}$ losses. Soil and plant tissue tests can be useful tools in making adjustments in $\mathrm{N}$ rates during the growing season using a feed back approach. Diagnostic midrib nitrate-N levels have been developed and published for several vegetablesproduced in thewestern $U$ nited States (D oergeet al., 1992). Q uick sap tests have also been evaluated and preliminary standardshave been published (H artz et al. 1994; Kubotaet al., 1996, 1997 ). A presidedress nitrate-N test has also been recently calibrated for vegetables ( $\mathrm{H}$ artz et al, 1998).

\section{Efficient irrigation}

Efficient irrigation isof paramount importance in achieving efficient $\mathrm{N}$ management even where split application or controlled release $\mathrm{N}$ applications are used. This is depicted in Fig. 8, which shows cabbage (Brassica ol er acea L. C apitata G roup) responses to sprinkler applied water and $\mathrm{N}$ rates (Sanchez et al., 1994). Although N was split into weekly applications through the irrigation system, marketable yield and $\mathrm{N}$ recoveries decreased and unaccounted for $\mathrm{N}$ increased as irrigation rates exceeded $100 \%$ consumptive use (CU) or evapotranspiration (ET). A nother illustration of this is shown with the midrib $\mathrm{NO}_{3}-\mathrm{N}$ data presented in Fig. 9 . Note that even with weekly $\mathrm{N}$ applications, themidrib nitrate- $\mathrm{N}$ values were continually below published critical concentrations when irrigation exceeded ET. These data are consistent with data we collected for other vegetable crops (Pier and Doerge, 1995; Sanchez et al., 1996; Stark et al., 1983; Thompson and Doerge, 1996) and underscore the importance of irrigation management to $\mathrm{N}$ fertilizer use efficiency.

\section{Literature cited}

Arnold, C.Y. 1974. Predicting stages of sweet corn (Zea mays L.) development. J. Amer. Soc. H ort. Sci. 99:501-505.

Cook, W.P. and D.C. Sanders. 1991. Controlled-release nitrogen sources and application timing for tomatoes. J. Prod. Agr. 4:198-203.

D oerge, T.A., J. Pier, and T. M cCreary. 1992 Watermelon response to soluble and slow release nitrogen fertilizers. Veg. Rpt. College Agr. Ser. P-93.

D oerge, T .A., R.L. Roth, and B.R. G ardner. 1991. Nitrogen fertilizer management in 
Arizona. U niv. Ariz. College Agr. Rpt. 191025.

Gardner, B.R. and W.D. Pew. 1979. Comparison of various nitrogen sources for the fertilization of winter-grown head lettuce. J. Amer. Soc. $\mathrm{H}$ ort. Sci. 104:534-536.

H artz, T.K. and W.E. Bendixen. 1998. Presidedressing soil nitrate testing (PSN T) effective in reducing $\mathrm{N}$ fertilizer use in vegetable production. H ortScience 33:534 (abstr.).

H artz, T.K., R.F. Smith, K.F. Schulbach, and M . L eStrange. 1994. O n farm nitrogen testsimprove fertilizer efficiency, protect ground water. Calif. Agr. 48:29-32.

Katz, Y.H . 1952. The relationship between heat units accumulation and the planting and harvesting of canning peas. Agron. J. 44:74-78.

Kubota. A., T.L. Thompson, T.A. Doerge, and R.E. Godin. 1996. A petiole sap nitrate test for cauliflower. H ortScience 31:934-937.

Kubota, A., T.L. Thompson, T.A. Doerge, and R.E. Godin. 1997. A petiole sap nitrate test for broccoli. J. Plant N utr. 20:669-682.

M adariaga, F.G. and J.E. Knott. 1951. Temperature summations in relation to lettuce growth. Proc. Amer. Soc. H ort. Sci. 58:147-152

Pier, J.W. and T.A. Doerge. 1995. Concurrent evaluationsof agronomic, economic, and environmental aspects of trickle irrigated water melon production. J. Environ. Q ual. 24:79-86.

Sanchez, C.A., R.J . Allen, and B. Schaefer. 1986.
G rowth and yield of crisphead lettuce under various shade conditions. J. Amer. Soc. H ort. Sci. 114:884-890.

Sanchez, C.A., R.L. Roth, and B.R. Gardner. 1994. Irrigation and nitrogen management for sprinkler-irrigated cabbage on sand. J. Amer. Soc. H ort. Sci. 119:427-433.

Sanchez, C.A., R.L. Roth, B.R. Gardner, and H. Ayer. 1996. Economic responses of broccoli and cauliflower to water and nitrogen on sand. $\mathrm{H}$ ortScience 31:201-205.

Stark, J.C., W.M. Jarrell, and J. Letey. 1983. Evaluation of irrigation-nitrogen management practices for celery using continuous-variable irrigation. Soil Sci. Soc. Amer. J. 47:95-98.

Thompson, T.L. and T.A. D oerge. 1996. N itrogen and water interactions in subsurface trickle irrigated leaf lettuce. II. Agronomic, economic, and environmental outcomes. Soil Sci. Soc. Amer. J. 60:168-173.

Walworth, J.L., D.E. C arling, and G.J . M ichaelson. 1992. N itrogen so urcesand ratesfor direct-seeded and transplanted lettuce. H ortScience 27:228230.

Wiedenfield, R.P. 1986. Rate, timing, and slowrelease nitrogen fertilizers on cabbage and onions. H ortScience 21:236-238.

Wurr, D.C.E., J.R. Fellows, and R.F. Suckling. 1988. Crop continuity and prediction of maturity in the crisphead lettuce variety Saladin. J. Agr. Sci. (Camb.) 111:481-486. 